\title{
The role of psychological capital and perceived organizational support on task performance: The mediating effects of individual readiness for change
}

\author{
G.F. Ramdhani \& P.M. Desiana \\ Faculty of Economics and Business, Universitas Indonesia, Indonesia
}

\begin{abstract}
This paper examines the role of psychological capital and perceived organizational support in task performance with individual readiness for change as a mediator. The data for this quantitative study were collected using questionnaires given to 223 employees who work in five telecommunication service provider companies in Indonesia. Structural equation modeling (SEM) using Lisrel software was used to present and analyze the obtained data. The result showed that individual readiness for change acted as a mediator in the causal relationship between psychological capital and perceived organizational support on task performance. However, perceived organizational support had no direct effect on task performance. This study discloses the importance of psychological capital and perceived organizational support in boosting the employees' task performance.
\end{abstract}

\section{INTRODUCTION}

The COVID-19 pandemic has brought changes to various aspects of life. As a result of the increasing number of COVID-19 cases in Indonesia, the government had implemented large-scale social restrictions that have resulted in the implementation of work from home to maintain business continuity (Haryono, 2020). The telecommunication service provider is one of the industrial sectors that are considered important to remain fully operational to meet the needs of the community amid the pandemic situation (Fachriansyah, 2020). This sector needs to significantly increase its role to support bandwidth demand due to the increasing data traffic (Haryono, 2020) and also to present additional programs (Evandio, 2020). The government through the Ministry of Education and Culture issued a policy of internet data quota assistance to help the process of distance learning (Jamaludin, 2020).

This condition illustrates that environmental dynamics make organizations always ready to face challenges in embracing change; therefore, individuals and organizations take roles in dealing with the changes (Shah, 2011). However, employees may feel insecure about the changes, which may, inadvertently, affect their performance (Cartwright \& Holmes, 2006). Organizations need high-performing individuals to achieve goals, increase productivity, and increase competitiveness (Sonnentag \& Frese, 2002). The level of employee performance can depend on the level of their readiness to face changes (Bellou \& Chatzinikou, 2015).

Individual readiness to change is shown through support, openness, and commitment to change. One of the factors that can influence these attitudes and behavior is personal characteristics (Palmer, Dunford, \& Buchanan, 2017). Organizations can increase their competitive advantage by managing the psychological capital of their employees (Luthans, Youssef, \& Avolio, 2007) and become more successful by creating positivity among employees, which can also improve employee performance (Tosten \& Toprak, 2017). 
In addition, factors that play a role in increasing individual readiness for change and facilitate effective performance are the need for organizations to support their employees. Organizational support is an effort to reward, pay attention to, and increase the welfare of each employee (Rhoades \& Eisenberger, 2002). The development of a positive impression regarding the support that employees receive will lead to positive outcomes for both the employee and the organization.

\section{LITERATURE REVIEW}

Koopmans et al. (2011) stated that task performance is an important dimension of individual performance. Task performance is defined as proficiency (that is, competence) or the ability to perform a core task or job, which is also often referred to as job-specific task proficiency, technical proficiency, or in-role performance.

Individual readiness for change is defined as the extent to which individuals feel ready or primed, either mentally, psychologically, or physically marked by participation, promotion, and resistance to participating in organizational development activities (Hanpachern, 1997). Individual readiness for change consists of three dimensions: (1) participation, (2) promotion, and (3) resistance.

Psychological capital is the state of positive psychological development of individuals which consists of four dimensions, namely, (1) self-efficacy, (2) hope, (3) optimism, and (4) resilience (Luthans, Youssef, \& Avolio, 2007).

The concept of perceived organizational support comes from organizational support theory, which states that perceived organizational support is a general belief of employees about the extent to which the organization can appreciate their contribution and also care about their welfare (Eisenberger, Huntington, Hutchison, \& Sowa, 1986).

\section{METHODOLOGY}

Data analyzed in this research were collected from five telecommunication service provider companies in Indonesia. One of the criteria for this research were employees who were actively working in the telecommunication service provider companies. The distribution of online questionnaires was carried out in three stages, including the wording test to 10 respondents, the pilot test to 30 respondents, and the main test to 223 respondents.

Fifty questions were adopted from previous relevant studies. Respondents were required to answer the questions on a 6-point Likert scale. The questionnaire used to measure task performance was the IWPQ developed by Koopmans (2015), which consists of five questions. Individual readiness for change was measured using 14 questions adopted from Hanpachern (1997). Psychological capital was measured using 24 questions adopted from PCQ-24 developed by Luthans, Youssef, and Avolio (2007). Perceived organizational support was measured using seven questions by Eisenberger, Cummings, Armeli, and Lynch (1997). The data were analyzed by using the structural equation technique or structural equation modeling (SEM)-Lisrel.

The hypotheses in this study are stated as follows:

H1: Psychological capital has positive and significant effects on individual readiness for Change.

$\mathrm{H}$ 2: Perceived organizational support has positive and significant effects on individual readiness for change.

H3: Psychological capital has positive and significant effects on task performance.

H4: Perceived organizational support has positive and significant effects on task performance.

H5: Individual readiness for change has positive and significant effects on task performance.

H6: Individual readiness for change mediates psychological capital on task performance.

H7: Individual readiness for change mediates perceived organizational support on task performance. 


\section{RESULTS}

The questionnaires were filled out by 169 men $(75.78 \%)$ and 54 women $(24.22 \%)$. The majority of respondents belonged to Generation $\mathrm{Y}$ or the 26-40 years age group (75.78\%). Most of them were bachelors and graduates $(83.4 \%)$. Around $77 \%$ had been working for the telecommunication service provider companies for $1-5$ years. Just over a half of them were working as staffs $(51.12 \%)$, and more than $75 \%$ of them were permanent employees.

The measurement model was assessed using validity, reliability, and goodness-of-fit indices. The validity was evaluated by the value of standardized loading factors (SLFs), while reliability was evaluated by the value of construct reliability (CR) and average variance extracted (AVE). The desirable value of SLF was 0.50; CR was 0.70; and AVE was 0.5 . All indicators in this study were above the criteria.

This study used nine goodness-of-fit indicators to test the overall model fit, which were RMSEA, NFI, NNFI, CFI, IFI, RFI, Std. RMR, GFI, and AGFI. There were five GoF indicators that resulted in a good fit. Meanwhile, the rest showed marginal fit and poor fit. Despite the four unsatisfactory GoF indicators found, the overall structural model had a good fit for the data. After ensuring the model, the hypotheses developed for this study were tested.

In this model, perceived organizational support had no direct effect on task performance $(\mathrm{SLF}=0.091$; $\mathrm{t}$-value $=1.40)$, denoting that H4 is not supported. However, perceived organizational support was found to have a positive and significant effect on individual readiness for change $(\mathrm{SLF}=0.21$; $\mathrm{t}$-value $=3.31)$, signifying that $\mathrm{H} 2$ is supported. Psychological capital was found to have a positive and significant effect on task performance $(\mathrm{SLF}=0.59$; $\mathrm{t}$-value $=7.48)$ and individual readiness for change $(\mathrm{SLF}=0.48$; $\mathrm{t}$-value $=7.21)$, indicating that $\mathrm{H} 1$ and $\mathrm{H} 3$ are supported. Individual readiness for change had a significant and positive effect on task performance $(\mathrm{SLF}=0.12$; $\mathrm{t}$-value $=1.83$ ), denoting that H5 is supported. Individual readiness for change was found to fully mediate the effect of psychological capital on task performance; therefore, H6 is supported. Furthermore, individual readiness for change was found to mediate the effect of perceived organizational support on task performance; thus, $\mathrm{H} 7$ is also supported.

\section{DISCUSSION}

The findings of this study showed that psychological capital had a positive and significant effect on individual readiness for change and task performance. This study supported the previous study done by Kirrane, Lennon, O'Connor, and Fu (2016). From the study, it can be said that psychological capital has an important role in organizational change because employees who feel more positive about their own ability to cope with challenges will be more prepared to face changes. Employees with high positive psychological capital will also do work simultaneously, so that they will strive to be successful by completing tasks well.

Perceived organizational support had a positive and significant effect on individual readiness for change. This finding is in line with another study done by Gigliotti, Vardaman, Marshall, and Gonzalez (2018), who showed that perceived organizational support was a key role during organizational change and had an impact on the reaction of the change recipients.

The results are also supported the previous research, which showed that individual readiness for change had a significant positive relationship with performance (Iqbal \& Asrar-ul-Haq, 2018). Employees will not compromise on their performance and are ready to accept organizational changes. However, organizational support had no direct effect on task performance. This result did not support the previous study done by Eisenberger, Huntington, Hutchison, and Sowa, (1986), who showed that perceived organizational support would improve employee performance as a function of socio-emotional needs.

Even so, individual readiness for change was found to mediate the effect of psychological capital and perceived organizational support on task performance. Change readiness acts as a mediator among personal characteristics, internal context enablers, and external pressures on performance 
based on the multilevel framework of the antecedents and consequences of readiness for change (Rafferty, Jimmieson, \& Armenakis, 2013).

This study also provides factors that affect task performance by investigating the role of psychological capital and perceived organizational support in individual readiness for change.

However, perceived organizational support had no direct effect on task performance. The findings also imply that the psychological capital and employees' perception of organizational support are important to increase their readiness to face changes and in turn influence their task performance.

\section{REFERENCES}

Bellou, V., \& Chatzinikou, I. 2015. Preventing employee burnout during episodic organizational changes. Journal of Organizational Change Management, 28(5), 673-688.

Cartwright, S., \& Holmes, N. 2006. The meaning of work: The challenge of regaining employee engagement and reducing cynicism. Human Resource Management Review, 16(2), 199-208.

Eisenberger, R., Huntington, R., Hutchison, S., \& Sowa, D. 1986. Perceived organizational support. Journal of Applied Psychology, 71, 500-507.

Evandio, A. 2020, March 18. 'Perang' Layanan ala Operator Telekomunikasi di Tengah Social Distancing. Retrieved September 20, 2020, from Bisnis.com: https://teknologi.bisnis.com/read/20200318/101/1215150/ perang-layanan-ala-operatortelekomunikasi-di-tengah-social-distancing

Fachriansyah, R. 2020, April 8. Jakarta will impose stronger mobility restrictions on Friday. Here's what you need to know. Retrieved August 12, 2020, from The Jakarta Post: https://www.thejakartapost. com/news/2020/04/08/jakarta-will-impose-stronger-mobilityrestrictions-on-friday-heres-what-you-needto-know.html

Gigliotti, R., Vardaman, J., Marshall, D., \& Gonzalez, K. 2018. The role of perceived organizational support in individual readiness. Journal of Change Management, 19(2), 86-100.

Hanpachern, C. 1997. The extension of the theory of margin: A framework for assessing readiness for change. Unpublished Doctoral Dissertation, Colorado State University, Fort Collins.

Haryono, H. 2020, June 3. Pandemi Covid-19 dan industri telekomunikasi. Retrieved September 20, 2020, from indotelko.com: https://www.indotelko.com/read/1591163164/pandemi-covid-19telekomunikasi

Iqbal, A., \& Asrar-ul-Haq, M. 2018. Establishing relationship between TQM practices and employee performance: The mediating role of change readiness. International Journal of Production Economics, 203, $62-68$.

Jamaludin, F. 2020, September 22. Ramai-ramai Operator Seluler Beri Bantuan Kuota Internet untuk PJJ. Retrieved September 27, 2020, from merdeka.com: https://www.merdeka.com/teknologi/ramairamaioperator-seluler-beri-bantuan-kuota-internet-untuk-pjj.html?page $=1$

Kirrane, M., Lennon, M., O'Connor, C., \& Fu, N. 2016. Linking perceived management support with employees' readiness for change: the mediating role of psychological capital. Journal of Change Management, $47-66$.

Koopmans, L., Bernaards, C., Hildebrandt, V., Schaufeli, W., de Vet Henrica, C., \& van der Beek, A. (2011). Conceptual frameworks of individual work performance: a systematic review. Journal of occupational and environmental medicine, 53(8), 856-866.

Luthans, F., Youssef, C. M., \& Avolio, B. J. 2007. Psychological capital: Developing the human competitive edge. Oxford: Oxford University Press.

Palmer, I., Dunford, R., \& Buchanan, D. 2017. Managing organizational change: A multiple perspective approach, 3rd edition. New York: McGraw Hill Education.

Rafferty, A., Jimmieson, N., \& Armenakis, A. 2013. Change readiness: A multilevel review. Journal of Management, 39(1), 110-135.

Rhoades, L., \& Eisenberger, R. 2002. Perceived organizational support: a review of the literature. Journal of Applied Psychology, 87, 698-714. doi: 10.1037/0021-9010.87.4.698.

Shah, N. 2011. A study of the relationship between organisational justice and employee readiness for change. Journal of Enterprise Information Management, 24(3), 224-236.

Sonnetag, S., \& Frese, M. 2002. Performance Concept and Performance Theory in Psychological Management of Individual Performance. Sussex: John Wiley \& Sons.

Tosten, R., \& Toprak, M. 2017. Positive psychological capital and emotional labor: A study in educational organizations.Cogent Education, 4(1), 1301012. 